\title{
Multidimensional Fair Fuzzy Equilibrium Evaluation of Housing Expropriation Compensation from the Perspective of Behavioral Preference: A Case Study from China
}

\author{
Zhaoyu Cao ${ }^{1,2}$, Xu Zhao ${ }^{3}$, Yucheng Zou ${ }^{2, *}$, Kairong Hong ${ }^{2}$ and Yanwei Zhang ${ }^{4, *(D)}$ \\ 1 School of Public Administration, Hunan University of Finance and Economics, Changsha 410205, China; \\ caozhaoyu@csu.edu.cn \\ 2 School of Business, Central South University, Changsha 410083, China; hongkairong@csu.edu.cn \\ 3 School of Management, Hunan City University, Yiyang 413000, China; zhaoxu@hcu.edu.cn \\ 4 College of Public Administration, Huazhong University of Science and Technology, Wuhan 430074, China \\ * Correspondence: 191611002@csu.edu.cn (Y.Z.); bsonyan@hust.edu.cn (Y.Z.); \\ Tel.: +86-150-8377-5106 (Yucheng Zou)
}

check for

updates

Citation: Cao, Z.; Zhao, X.; Zou, Y.;

Hong, K.; Zhang, Y.

Multidimensional Fair Fuzzy

Equilibrium Evaluation of Housing

Expropriation Compensation from

the Perspective of Behavioral

Preference: A Case Study from China.

Mathematics 2021, 9, 650. https://

doi.org/10.3390/math9060650

Academic Editor: David Barilla

Received: 27 January 2021

Accepted: 15 March 2021

Published: 18 March 2021

Publisher's Note: MDPI stays neutral with regard to jurisdictional claims in published maps and institutional affiliations.

Copyright: (c) 2021 by the authors. Licensee MDPI, Basel, Switzerland. This article is an open access article distributed under the terms and conditions of the Creative Commons Attribution (CC BY) license (https:/ / creativecommons.org/licenses/by/ $4.0 /)$.

\begin{abstract}
With the rapid development of urbanization, substantial land areas and houses are expropriated, which can cause huge numbers of disputes related to expropriation compensation. The root of the disputes is that the associated subjects are affected by various behavioral preferences and make different cognitive fairness judgments based on the same compensation price. However, the existing expropriation compensation strategies based on the market value under the assumption of "the economic man" hypothesis cannot meet the fairness preference demands of the expropriated. Therefore, finding a compensation price that satisfies subjects' multidimensional fairness preferences, including profit-seeking, loss aversion, and interactive fairness preferences, is necessary. Only in this way can the subjects reach an agreement regarding fair compensation and resolve their disputes. Because of the fuzziness of subjects' expected revenues, this paper innovatively introduces trigonometric intuitional fuzzy numbers to construct one-dimensional and multidimensional fair fuzzy equilibrium evaluation models. The Technique for Order Preference by Similarity to an Ideal Solution (TOPSIS) method is adopted to convert a multidimensional problem into a multiattribute group decision problem, which simplifies the problem of finding multidimensional equilibrium when considering the multidimensional fairness preferences of the two subjects. Real case data are introduced to verify the validity of this method. The research results show that upward revision of the multidimensional fairness preferences based on the market value assists in achieving a fair compensation agreement. Consideration of the influence of the subjects' multidimensional fairness preferences on the fairness equilibrium is conducive to resolving the disputes, and provides a reference for the settlement of expropriation compensation disputes in developing countries.
\end{abstract}

Keywords: multidimensional fairness; fuzzy equilibrium evaluation; housing expropriation compensation; dispute resolution; TOPSIS method

\section{Introduction}

In recent years, rapid development and urbanization has led to constant expropriation of land and housing in developing countries [1]. China has become one of the world's fastest urbanizing countries today [2]. However, urbanization inevitably leads to urban expansion and redevelopment [3]. In China's government work report of 2019, the Chinese central government pointed out that this new type of urbanization should be further promoted and that the construction of low-income housing and the renovation of rundown areas should be continued to ensure the basic housing needs of the population [4]. There are many old communities in cities and towns that need to be extensively renovated. The expropriation of houses in the nature of public interests, such as the reconstruction of old 
cities and the renovation of rundown areas, is a part of major livelihood projects that are undertaken to achieve urban renewal and promote economic and social development. In order to carry out reconstruction of old city areas, the primary tasks are to demolish the original houses and cooperate in the recovery of land use rights. According to the Chinese Family Panel Studies (ISSS, 2017), during the past two decades, approximately $10 \%$ of Chinese households in old towns or suburbs have experienced housing expropriation and relocation projects intended to make room for new development programs, and the population involved may exceed 100 million [5]. However, such rapid urbanization is a double-edged sword, with wide-ranging economic, social, and environmental effects. While these effects can enhance economic growth and increase national wealth, they can also lead to violence, conflicts, and poverty [6]. Regarding housing expropriation compensation in China, local governments (the expropriator), as independent stakeholder and administrative agents of the central government, are very eager to increase wealth through housing expropriation under the strong drive of financial and political interests. Within this context, it is easy for unreasonable standards of expropriation compensation and unfair distribution of benefits to occur, triggering disputes among social groups. Since 2000, China's central and eastern economic development areas have seen large numbers of "quick wealth" and "second-generation expropriation" agents (a popular folk metaphor in China refers to those who have made huge amounts of money through expropriation compensation), as well as "nail households" (a Chinese term for those who refuse to give up the house or land), sometimes even resulting in self-immolation to resist the expropriation, along with other vicious incidents. It can be seen that the contradictions caused by housing expropriation and relocation have been a major threat to social stability in China [7].

It is not difficult to see from these fierce housing expropriation conflicts that the focus of the disputes is on the expropriation compensation price, as the associated subjects cannot agree on a compensation price. The associated housing expropriation compensation subjects include the expropriator and the expropriated. According to the cases of expropriation compensation from 2003 to 2015, it was found that simply raising the compensation price and giving the expropriated a compensation price equal to the market value cannot restrain or eliminate the dispute, and the demands of the expropriated can be flexible and ambiguous [8]. This phenomenon cannot be explained by traditional game theory. In traditional game research, the behavioral choices of the subjects are determined by the relative magnitude of their payoffs, and the payoffs of the subjects are usually expressed in terms of their utility; that is to say, in traditional game logic, subjects pursue the maximization of their own utility [9]. According to this logic, in housing expropriation compensation scenarios, the realistic manifestation of the expropriated person's pursuit of maximum utility is to raise the expropriation compensation standard to the price equivalent to the market value. In theory, raising the standard of expropriation compensation should enable the expropriator and the expropriated to move from conflict to cooperation. However, this is not always so, because traditional game research does not consider the increase or decrease of the psychological utility brought about by the income of the subjects. In other words, the utility levels of the subjects include not only the utility in the form of economic income, but also their psychological utility. In the actual expropriation process, the subjects not only focus on whether their income is maximized and whether their losses are minimized [10], but also pay attention to the differences between their gains and expectations, as well as the differences between their gains and those of others. In other words, the subjects not only focus on the compensation price, but also pay attention to whether the income distribution is fair and whether it has met their expectations. The increase or decrease of psychological utility caused by the inconsistency between actual income and psychological expectation directly affects the utility of the subjects. From the above analysis, it can be seen that regarding housing expropriation compensation, the associated subjects are not only affected by profit-seeking preferences, but also by loss aversion and interactive fairness preferences. If there is still a gap in the distribution of benefits among the subjects while raising the price of expropriation compensation or the benefits are far from their psychological expectations, 
then no agreement can be reached. In fact, the behavior of any game subject will produce belief interactions, which will inevitably lead to changes of psychological utility [11]. Therefore, from the perspective of individual psychological characteristics, belief cognition, and behavioral preference, we should consider the influence of irrational emotional factors on the behavioral choices of the subjects [12]. Only by considering both material benefits and psychological benefits can we more accurately reveal the underlying causes of the subjects behavior. The game equilibrium is the result of the strategic and belief interactions of the subjects under the influence of behavioral preferences. Applying this logic to the housing expropriation compensation scenarios, it can be seen that the subjects' different perceptions of fair compensation are the root of expropriation compensation disputes. The primary contradictions in housing expropriation compensation are the homogenization of pricing and the differentiation of compensation demands [13]. Taking the hypothesis of "economic man", compensation for housing expropriation based on the market value cannot meet the fairness preference demands of the expropriated [14]. Therefore, ensuring that the government (the expropriator) pricing is relatively reasonable and meets the heterogeneous interest demands of the expropriated is very important in solving disputes [15].

Therefore, in expropriation compensation disputes, how do the behavioral preferences of the subjects affect the expropriation compensation game equilibrium? How can the fairness preference demands of the associated subjects under the influence of multiple behavioral preferences be satisfied? If the expected income for both associated subjects is fuzzy, how can an expropriation compensation price that satisfies both parties and that moves the exchange conflict to cooperation be found? These are problems worth studying.

When the subjects of housing expropriation compensation are affected by a single profit-seeking preference, the subjects are purely self-interested, creating a perfectly rational scenario; that is, the subjects make strategic choices for the purpose of maximizing their own interests. In such cases, although the combination of the expropriator's choice of a fair expropriation proposal and the expropriated person's choice of acceptance can achieve the Pareto optimality, the associated subjects will deviate from the strategy combination of fair expropriation and acceptance under the influence of the idea of maximizing benefits. At this time, the game equilibrium between unfair expropriation by the expropriator and resistance by the expropriated occurs. When the subjects are not only affected by profitseeking preferences, but also by loss aversion and interactive fairness preferences, the scenario becomes a bounded rational game. Namely, the subjects not only pursue the maximization of their own interests as the only goal, but also take the minimization of losses as a goal and care about the differences between their own income and expectations, as well as the differences between their own income and the income of other subjects [16]. All of these factors will cause changes to the psychological utility of the subjects, which in turn will affect the total utility of the subjects. The equilibrium logic of the associated subjects under the influence of various behavioral preferences will no longer equal the strategic interactive equilibrium under the motive of maximization of material benefits, however the belief interactive equilibrium jointly determined by profit-seeking preference, loss aversion preference, and interactive fair preference will prevail. When the fairness preference demands of the subjects are not satisfied, it is difficult to reach an agreement on the compensation price and the dispute will lead to conflicts among groups. There will be a sequence of disputes and conflicts. Disputes are the initial stages of conflicts, which can also be classified as low-level conflicts. Conflict is a broad term that covers everything from non-violent tensions, struggles, disputes, and litigation to violence, and it is also defined as a dispute or incompatibility between actual or envisaged needs, values, and interests [17]. Conflicts are the result of long-term accumulation. They are often difficult to resolve and have many adverse consequences, such as mass demonstrations, suicides, and group fights. The most important way to solve the conflict is to find the root cause of the expropriated person's resistance to expropriation. Only by understanding the real reason can conflict turn to cooperation. Therefore, in-depth analysis of the behavioral preference laws of the stakeholders in housing expropriation compensation conflicts, as well as the 
influences on the game equilibrium, must be carried out to find an effective way to solve expropriation compensation disputes. This has become a practical problem that needs to be solved urgently on the road to China's new urbanization goals.

\section{Literature Review}

According to the existing literature at home and abroad, scholars have studied disputes related to expropriation compensation from different perspectives. Most scholars have analyzed the behavioral characteristics and strategy choices of participants in the expropriation compensation dispute from the perspective of evolutionary game theory, explaining how the expropriation disputes evolve and studying the influencing factors and governance methods that lead to the expropriation conflicts [18-23]. Although evolutionary game theory can explain people's behavioral decisions from the perspective of bounded rationality, bounded rationality includes the phenomenon of infinite rationality [24]. It is difficult to describe people's irrational behaviors under the influence of behavioral preference. Williamson's research in 1981 found that the distribution of benefits between subjects is affected by their behavior preferences [25]. Behavioral economist Cameron concluded through research that people's attention and psychological tendency towards the interests and behavior of others are manifested as social preferences [26]. For the participants in the housing expropriation compensation scenario, namely the expropriator (the government) and the expropriated, their strategic choices will inevitably be affected by behavioral preferences. For example, the expropriated person's dissatisfaction with the compensation standard, their worries about life after housing expropriation, and the understanding of the public interest of the expropriator (the government) will be reflected in specific behavior and strategic choices. The expropriator's desire for financial and political benefits and the sympathy for the expropriated person's weak position in the distribution of interests will also be incorporated into their strategic choices. In short, the subjects' behavioral preferences play an important role in exacerbating or mitigating the conflict of housing expropriation compensation. In reality, people's behavioral decisions are not only driven by interests, but are also influenced by various preferences, which dominate the individual's beliefs, judgments, and choices [27].

In recent years, a large number of experimental studies have proven that people are not completely self-involved. They not only care about their own benefits, but also pay attention to the benefits of others. They are even willing to sacrifice part of their benefits to help the friendly and punish the unfriendly, which is reflected in the interactive fairness preference of the subjects [28-32]. Rabin elaborated the concepts of fair preference and fair equilibrium, and pointed out that under the self-interested basic preference of "rational man", the subject also cared about the gap between their own income and others and whether it had been fairly distributed, and constructed a "friendly function" to quantify the fairness preferences [33]. On this basis, Fehr and Schmidt used a mathematical model to express the utility function of the fairness preference, namely the inequity aversion model, which explained the final results of the ultimatum game and gift exchange experiments: the change of utility caused by the income comparison between participants [34]. Based on previous research results, Bolton and Ockenfels studied the payment behavior and relative payment value of the subject under the condition of incomplete information and constructed an inequity aversion model. The experimental results proved the consistency of the model and explained the role of fairness belief in game experiments [35]. The research field of fairness theory also produces a series of research results. Dufwenberg and Kirchsteiger discussed the dynamic structure of games and constructed a sequential interactive equilibrium model [36]. Falk and Fischbacher studied the N-person extended game and constructed an interactive equilibrium model [37]. Tang and others believed that fairness preference refers to people's preference to pay attention to others' individual welfare and fair distribution and motivation among social members besides their own material interests [38]. Kohler established the set preference model of altruism and fairness [39]. Raúl constructed an honest and fairness set preference game model [40]. Wang 
and Lu concluded that the perception of fairness of people have who have experienced expropriation of urban housing has a positive impact on their intention to expropriate and a negative impact on their willingness to compensate [41]. Zhang and Zhang introduced the fair psychological preference, constructed the social function of the utility of fair psychological preference, and applied the social psychological utility function to the compensation game model of land development projects [42]. Baldassarri concluded that altruism or group unity is not the root cause of cooperation and that cooperation is not caused by altruism or group solidarity. In contrast, repeated interactions are conducive to the development of the reciprocity mechanism [43]. Liu and Hong introduced the idea of interactive fairness into game analysis [44]. Wang and Tong pointed out that in addition to the self-interest preference, the fairness preference has an important impact on the redistribution of decision-making [45]. Wang and Wang concluded that retailers' fairness preference not only affects the pricing strategy and profit of retailers and manufacturers, but also affects the systemic income distribution of the whole supply chain [46]. Zhang and others concluded that under Fehr and Schmidt fairness preference model, the profit of each member in the supply chain is less than or equal to the profit under the fair neutral model, however under the Bolton and Ockenfels fairness preference model, the profit of each member in the supply chain is greater than or equal to the profit under the fair neutral model [47].

According to the existing research on fairness preference in academia, participants involved in housing expropriation compensation disputes will experience changes in psychological utility and fairness equilibrium under the influence of interactive fairness preference. Among them, the inequity aversion model constructed by Fehr and Schmidt has been demonstrated and applied in academia for many years, and it has been proven to be a basic model that quantifies the utility changes brought about by the fairness preferences of the subjects. Therefore, in housing expropriation compensation conflicts, this paper also uses this model to observe the subjects' strategic choices and changes in fairness equilibrium under the influence of fairness preferences.

Another key incentive in disputes over compensation for housing expropriation is the cognitive difference between the two parties in terms of the house value. Under the influence of the endowment effect, the expropriated person believes that the value of their expropriated house is higher than the market value provided through the valuation of the housing appraisal agency. There is a Chinese proverb that vividly describes the endowment effect of the expropriated person-golden nests and silver nests are not as good as their own dog nests. The meaning is equivalent to the English proverb, east or west, home is best. When people own something, they value it much more than when they do not own it. Because of the endowment effect, people want to avoid losing what they have and are more afraid of the possible change. Therefore, Kahneman and Tversky put forward the concept of loss aversion; that is, compared with the reference point, the psychological utility of equal loss is greater than that of equal gain [48]. Thaler introduced loss aversion into a non-risk field and explained the endowment effect, which refers to the fact that individuals place a higher value on the goods that they already own than when they did not own these goods [49]. Tversky and Kahneman constructed the subject utility function according to the psychological utility characteristics of the subject [50]. Shalev put forward the concept of the loss aversion equilibrium of a repeated game, defined a particular type of loss aversion function, and combined this function with the payment functions of the repeated game to evaluate the risk aversion behavior in repeated games, through which the infinitely repeated game equilibrium in extreme loss aversion situations and a loss aversion model can be constructed [51,52]. Gimpel studied loss aversion equilibrium in multiattribute negotiations [53]. Driesen and others analyzed the loss aversion equilibrium in bargaining games [54]. Ahrens and others proposed a new price adjustment partial equilibrium theory using consumer loss aversion [55]. Enrico and De studied loss aversion using state-dependent reference points [56]. Xu and others discussed forming mechanism and management countermeasures in terms of people's sense of income injustice from 
the dual perspective of reference dependence and loss aversion [57]. The above studies have laid the foundation for the development of loss aversion theory. Loss aversion theory can explain many phenomena in economic activities. For example, people tend to believe that the expropriator pays too little for the house they own, while the expropriator thinks that the value of the expropriated house far exceeds the amount they are willing to pay; therefore, the two cannot reach an agreement on the expropriation compensation price, which leads to a dispute over expropriation compensation. Although loss aversion may cause disputes, on the other hand, it can also help resolve disputes. In the dispute of expropriation compensation, the negative influences of government reputation and social stability can be regarded as the losses that the expropriator does not want to bear. When the expropriator is affected by the fairness preference of loss aversion, they will try to meet the requirements of the expropriated to achieve harmonious expropriation, so as to prevent more losses caused by compensation disputes.

In the field of housing expropriation compensation, there is no lack of research from the perspective of behavioral preference, however previous studies focus solely on the influence of behavioral choices or psychological changes of participants in expropriation compensation disputes, in addition to rare examples of multidimensional fair fuzzy equilibrium evaluation research. Based on the perspective of behavioral preference, this paper first proposes that the key to resolving housing expropriation compensation disputes lies in the fact that the associated subjects form a consensus on beliefs and strategies for expropriation compensation, satisfying the subjects' multidimensional fairness demands under the influence of profit-seeking preference, loss aversion, and interactive fairness preference, and achieve the fairness equilibrium under the interaction of the strategies and beliefs of the associated subjects. This multidimensional fairness equilibrium is essentially a combinatorial equilibrium of multiagent, multistrategy, and multipreference factors, which helps resolve disputes over expropriation compensation. Based on this, an innovative multiagent, multistrategy, multipreference, multidimensional equilibrium evaluation method is proposed. The Technique for Order Preference by Similarity to an Ideal Solution (TOPSIS) method is introduced to transform the multidimensional fuzzy equilibrium evaluation solution into the multiattribute group decision-making sorting problem, while the optimal solution is the multidimensional fair fuzzy equilibrium evaluation solution. The obtained multidimensional fair fuzzy equilibrium evaluation solution can satisfy the multidimensional fairness demands of the subjects at the same time. The subjects reach an agreement on the compensation standard, which makes them move from conflict to cooperation. It also provides a reference for the settlement of expropriation compensation disputes in other developing countries.

\section{Modeling}

\subsection{Assumptions}

This paper discusses the establishment of a multidimensional fairness equilibrium evaluation model that places the subjects' profit-seeking, loss aversion, and interactive fairness attitudes within the same analytical framework. To facilitate the research and analysis, the following assumptions are proposed.

1. In the housing expropriation compensation model, only two associated subjects exist: the expropriator A and the expropriated person B. Moreover, the assumption is that both subjects have a multidimensional fairness preference. The expropriator has two strategies: fair price and unfair expropriation prices. "Fair price" is a type of subjective judgment. The determination of a fair price is different under various preferences. In a situation of profit-seeking fairness, the fair price is the compensation price determined by the housing appraisal agency, is based on the market method, and is accepted by all subjects. In the case of loss aversion fairness, the fair price is the compensation price accepted by both subjects after considering their loss aversion fairness. Regarding interactive fairness, the fair price is the compensation price accepted by both subjects after considering the interactive fairness. In a situation of a multidimensional fairness 
preference, the fair price is the compensation price accepted by the subjects after considering profit-seeking, loss aversion, and interactive fairness factors. The unfair price is a compensation price that is lower than the fair price. Considering that most expropriated individuals have expropriation intentions and only some of them expect to gain more compensation by resisting the expropriated person is assumed to have two strategies: acceptance and acceptance after resistance.

2. Compensation for housing expropriation is uncertain. The associated subjects' judgments on expectations for the future and their own losses contain fuzziness-they can neither accurately judge the size of their income nor measure their own losses, and often re-evaluate their gains and losses as the situation changes or assess their gains and losses within the scope of a certain value. In other words, the acquisition of relevant benefits for the subjects is hesitant and the future benefits are fuzzy. Therefore, this paper introduces triangular intuitionistic fuzzy numbers. The trigonometric intuitionistic fuzzy numbers are introduced into this paper to measure the utility of associated subjects of housing expropriation compensation and to study a multidimensional fair fuzzy equilibrium evaluation involving multiagent and multipreference factors of housing expropriation compensation. Suppose that when B adopts an acceptance strategy, A's utility of a fair expropriation price is $<\left(\underline{s}_{1}, s_{1}, \overline{s_{1}}\right), w_{\widetilde{a}_{1}}, u_{\widetilde{a}_{1}}>$; B's utility is $\left\langle\left(\underline{h_{1}}, h_{1}, \overline{h_{1}}\right), w_{\widetilde{b}_{1}}, u_{\widetilde{b}_{1}}>\right.$; A's utility of an unfair expropriation price is $\left\langle\left(\underline{s}_{2}, s_{2}, \overline{s_{2}}\right), w_{\widetilde{a}_{2}}, u_{\widetilde{a}_{2}}>\right.$; B's utility is $<\left(\underline{h_{2}}, h_{2}, \overline{h_{2}}\right), w_{\widetilde{b}_{2}}, u_{\widetilde{b}_{2}}>$. When B adopts a resistance strategy, A's utility of a fair expropriation price is $<\left(\underline{s}_{3}, s_{3}, \overline{s_{3}}\right), w_{\widetilde{a}_{3}}, u_{\widetilde{a}_{3}}>$, while B's utility is $<\left(\underline{h_{3}}, h_{3}, \overline{h_{3}}\right), w_{\widetilde{b}_{3}}, u_{\widetilde{b}_{3}}>$; A's utility of an unfair expropriation price is $\left\langle\left(\underline{s}_{4}, s_{4}, \overline{s_{4}}\right), w_{\widetilde{a}_{4}}, u_{\widetilde{a}_{4}}>\right.$, while B's utility is $\left\langle\left(\underline{h_{4}}, h_{4}, \overline{h_{4}}\right), w_{\widetilde{b}_{4}}, u_{\widetilde{b}_{4}}\right\rangle$. The subscript numbers represent the combination of plans when the subjects adopt different strategies, whereby a 1 represents fair expropriation price by the expropriator and acceptance by the expropriated person, 2 represents an unfair expropriation price by the expropriator and acceptance by the expropriated person, 3 represents a fair expropriation price by the expropriator and resistance by the expropriated person, and 4 represents an unfair expropriation price by the expropriator and resistance by the expropriated person. Here, $s_{1}$ represents the utility most likely acquired by expropriator A under the fair expropriation price-acceptance scheme, while $h_{1}$ represents the utility most likely acquired by the expropriated person $B$ under the fair expropriation price-acceptance scheme. Assuming that utility $s_{1}$ is a linear function of the expropriator's income and cost, $\mathrm{F}$ represents the total income and $\mathrm{C}$ represents the expropriation compensation price paid to the expropriated person when the expropriator adopts the fair expropriation price strategy. To simplify the calculation, taxes are not considered in the calculation and the equation $s_{1}=F-C$ is used in the calculation process. The expropriation compensation price is the appraisal price determined by a housing appraisal agency under a profit-seeking fairness preference. The utility of the expropriated person is assumed to be a linear function of the expropriation compensation price when the expropriated person accepts the expropriator's fair expropriation price, which can be expressed as $h_{1}=C$. The letters $a$ and $b$ in the subscript stand for the expropriator A and the expropriated person $B$, respectively. The letters combined with different numbers represent the associated subjects (the expropriator A or the expropriated person B) under a certain combination of strategies. For example, $a_{1}$ represents the expropriator A under the fair expropriation price-acceptance scenario; $b_{2}$ represents the expropriated person $B$ under the unfair expropriation price-acceptance scenario; $w$ and $u$ represent the maximum membership degree and the minimum non-membership degree, respectively. Combined with the subscript, $w$ and $u$ represent the maximum membership degree and minimum non-membership degree of the utility obtained by the associated subjects under a certain scheme combination, respectively; $w_{\widetilde{a}_{1}}$ and $u_{\widetilde{a}_{1}}$ represent the maximum membership degree and the minimum non-membership degree that the expropriator $\mathrm{A}$ obtains for the utility value under the fair expropriation price-acceptance scheme, 
respectively; $w_{\widetilde{b}_{2}}$ and $u_{\widetilde{b}_{2}}$ represent the maximum membership degree and the minimum non-membership degree that the expropriated person B obtains for the utility value under the unfair expropriation price-acceptance scheme, respectively.

3. We set the reference dependency value of expropriator $\mathrm{A}$ as $<\left(k_{a}, k_{a}, \overline{k_{a}}\right), w_{k_{a}}, u_{k_{a}}>$ and the reference dependency value of expropriated person B as $\left.<\underline{\left(k_{b}\right.}, k_{b}, \overline{k_{b}}\right), w_{k_{b}}, u_{k_{b}}>$, whereby $k$ represents the reference dependency value and $w_{k_{a}}$ and $u_{k_{a}}$ represent the maximum membership degree and minimum non-membership degree of the reference dependency value of the expropriator, respectively; $w_{k_{b}}$ and $u_{k_{b}}$ represent the maximum membership degree and minimum non-membership degree of the reference dependency value of the expropriated person. Normally, A's reference dependence value is the highest value of its expected revenue; therefore, A's reference dependence value is usually $<\left(\underline{s}_{2}, s_{2}, \overline{s_{2}}\right), w_{\widetilde{a}_{2}}, u_{\widetilde{a}_{2}}>$. Additionally, the reference dependency value of $\mathrm{B}$ is often the highest income level that the expropriated person expected.

\subsection{One-Dimensional Fair Fuzzy Equilibrium Evaluation Model}

To develop a multidimensional fair fuzzy game model for housing expropriation, first a one-dimensional fair fuzzy equilibrium evaluation model must be established; that is, a one-dimensional fair fuzzy equilibrium evaluation model for profit-seeking, loss aversion, and interactive factors. On this basis, three types of fairness are put into the same analytical framework to build a multidimensional fair fuzzy equilibrium evaluation model.

\subsubsection{Profit-Seeking Fair Fuzzy Equilibrium Evaluation Model}

Regarding the housing expropriation compensation, when the associated subjects are only affected by the profit-seeking preference and aim to pursue their own interests and utility maximization, the game strategy mainly depends on the utility of the associated subjects. Only when the utilities of the associated subjects are determined can the profitseeking fair fuzzy equilibrium evaluation model be constructed. Assuming that the utility function of the subject is a linear function of its benefits and costs, combined with the assumptions in Section 3.1, the one-dimensional fair fuzzy equilibrium evaluation matrix under profit-seeking preference is obtained, as shown in Table 1.

Table 1. Profit-seeking fair fuzzy equilibrium evaluation matrix.

\begin{tabular}{ccc}
\hline \multirow{2}{*}{ The Expropriator A } & \multicolumn{2}{c}{ The Expropriated Person B } \\
\cline { 2 - 3 } & Acceptance & Resistance \\
\hline \multirow{2}{*}{ Fair Expropriation Price } & $<\left(\underline{s}_{1}, s_{1}, \overline{s_{1}}\right), w_{\widetilde{a}_{1}}, u_{\widetilde{a}_{1}}>$, & $<\left(\underline{s_{3}}, s_{3}, \overline{s_{3}}\right), w_{\widetilde{a}_{3}}, u_{\widetilde{a}_{3}}>$, \\
& $<\left(\underline{h_{1}}, h_{1}, \overline{h_{1}}\right), w_{\widetilde{b}_{1}}, u_{\widetilde{b}_{1}}>$ & $<\left(\underline{h_{3}}, h_{3}, \overline{h_{3}}\right), w_{\widetilde{b}_{3}}, u_{\widetilde{b}_{3}}>$ \\
Unfair Expropriation Price & $<\left(\underline{\underline{s}}, s_{2}, \overline{s_{2}}\right), w_{\widetilde{a}_{2}}, u_{\widetilde{a}_{2}}>$, & $<\left(\underline{s_{4}}, s_{4}, \overline{s_{4}}\right), w_{\widetilde{a}_{4}}, u_{\widetilde{a}_{4}}>$, \\
& $<\left(\underline{h_{2}}, h_{2}, \overline{h_{2}}\right), w_{\widetilde{b}_{2}}, u_{\widetilde{b}_{2}}>$ & $<\left(\underline{h_{4}}, h_{4}, \overline{h_{4}}\right), w_{\widetilde{b}_{4}}, u_{\widetilde{b}_{4}}>$ \\
\hline
\end{tabular}

Under the influence of profit-seeking preference, if the compensation price is lower than $C$, then $s_{2}>s_{1}, h_{2}<h_{1}$. If the expropriator adopts a fair expropriation price and the expropriated person resists, the expropriator needs to pay an extra resistance cost $\mathrm{d}$ to deal with the resistance. Then, the utility of the expropriator is $s_{3}<s_{1}$. In this circumstance, it is difficult for the expropriated person to obtain more expropriation compensation. In contrast, the expropriated person needs to pay resistance cost $r$, and $h_{3}<h_{1}$. When the expropriated person adopts a resistance strategy, for the expropriator to obtain more utility under the unfair expropriation price is difficult. Therefore, the expropriated person eventually receives a fair compensation price. In this paper, we assume that when B adopts a resistance strategy, A's fair expropriation price utility is the same as that of the unfair expropriation price, which is $s_{3}=s_{4}, h_{3}=h_{4}$. In the case of an unfair expropriation price, if the cost of resistance paid by the expropriated person is lower than the difference between the fair and the unfair compensations, then $h_{4}>h_{2}$; otherwise, $h_{2}>h_{4}$. 
According to Table 1, under the influence of profit-seeking preference, the expropriator takes the dominant position in the bid, and the unfair expropriation price is the expropriator's dominant strategy. When the expropriator chooses an unfair expropriation price, the expropriated person's strategy depends on the utility of $<\left(\underline{h_{2}}, h_{2}, \overline{h_{2}}\right), w_{\widetilde{b}_{2}}, u_{\widetilde{b}_{2}}>$ and $<\left(\underline{h_{4}}, h_{4}, \overline{h_{4}}\right), w_{\widetilde{b}_{4}}, u_{\widetilde{b}_{4}}>$. In the actual housing expropriation process, $\mathrm{B}$ needs to pay a higher resistance cost to obtain fair compensation, $<\left(\underline{h_{4}}, h_{4}, \overline{h_{4}}\right), w_{\widetilde{b}_{4}}, u_{\tilde{b}_{4}}>$ is less than $<\left(\underline{h_{2}}, h_{2}, \overline{h_{2}}\right), w_{\widetilde{b}_{2}}, u_{\widetilde{b}_{2}}>$, and B's optimal strategy is acceptance. The unfair expropriation price-acceptance scenario becomes the equilibrium game strategy for the associated subjects, and this is also the strategy most expropriated people will choose; the other option is resistance. Another small part of the attempt by the expropriated person to obtain far higher compensation than the unfair compensation price is through extreme means of resistance. At this time, the unfair expropriation price-resistance scenario becomes the game equilibrium strategy. Two of these types of evaluation results are not ideal. They are not only detrimental to social equity, but also easily cause social conflicts. Therefore, this equilibrium result for the game under profit-seeking fairness conditions makes achieving the goal of harmonious expropriation difficult.

\subsubsection{Loss Aversion Fair Fuzzy Equilibrium Evaluation Model}

Prospect theory shows that when people are affected by loss aversion, they will subconsciously increase the probability of gain and reduce the probability of loss [58]. While considering the maximization of their own interests, the associated subjects also show the behavioral preference of pursuing the minimization of losses, and people are more concerned about their losses than their gains. The subjects will have different behavior choices when facing different degrees of loss risk and different benefits. Based on this logic, Shalev constructed the loss aversion utility function to determine the utility function of the game subject under the influence of loss aversion. Among them, the utility value of the subject not only includes material benefits, but also depends on the difference between their own benefits and psychological expectations (reference points). Therefore, it can also be regarded as a reference dependence function, which includes the criterion of the reference dependence in the psychological gain and loss utility of the subjects and reflects their behavior choices. In housing expropriation compensation, an expropriation project is complex, faced with many kinds of uncertain factors and unpredictable risks, such as the dissatisfaction of the expropriated person based on the expropriation price, which can lead to boycott and bring about certain losses, including the conflict cost of resisting the expropriation, the loss of missing work due to the project delay, and the information cost of regaining the interests of the expropriated person. These losses will affect the strategy choice of the expropriator, such as to complete the expropriation at the cost of increasing compensation. According to the analysis in Section 3.2.1, reaching equilibrium (fair expropriation price-acceptance) and the goal of harmonious expropriation based on the single profit-seeking fairness preference is difficult. On the basis of the previous analysis, when all of the subjects are affected by loss aversion, the fair compensation price should be based on the market price and the influence of the loss aversion on the expropriation compensation price should also be considered. According to this analysis logic, we construct the loss aversion utility value function with reference to the Shalev model, establish the house expropriation compensation game matrix for loss aversion preference, construct the expected utility function containing the psychological utility value of loss aversion, perform equilibrium analysis, and obtain the loss aversion equilibrium solution, so as to obtain the housing expropriation compensation game equilibrium that contains loss aversion preference under the interaction of strategies and beliefs based on the profit-seeking preference. After loss aversion is introduced, the utility of the subject is shown in Equation (1):

$$
U_{i}=\left\{\begin{array}{l}
x_{i}, x_{i} \geq r_{i} \\
x_{i}-\lambda_{i}\left(r_{i}-x_{i}\right), x_{i}<r_{i}
\end{array}\right.
$$


where $i$ is the player, $x_{i}$ is the benchmark value, $r_{i}$ is the reference dependence value, $\lambda_{i}$ is the loss aversion level of the player, and $0 \leq \lambda_{i}<1$. The larger the $\lambda_{i}$ value, the stronger the loss avoidance; $\lambda_{i}=0$ means the expected utility is maximized (the utility function of player $i$ has no reference dependence). The Shalev model [51] is used to modify the risk of the benchmark value. The fuzzy equilibrium evaluation matrix of loss aversion is shown in Table 2.

Table 2. Loss aversion fair fuzzy equilibrium evaluation matrix.

\begin{tabular}{|c|c|}
\hline The Expropriator A & Acceptance of Expropriated Person B \\
\hline Fair Expropriation Price & $\begin{array}{l}<\left(\underline{s}_{1}, s_{1}, \overline{s_{1}}\right), w_{\widetilde{a}_{1}}, u_{\widetilde{a}_{1}}>-\lambda_{a}\left(<\left(\underline{k_{a}}, k_{a}, \overline{k_{a}}\right), w_{k_{a}}, u_{k_{a}}>-<\left(\underline{s}_{1}, s_{1}, \overline{s_{1}}\right), w_{\widetilde{a}_{1}}, u_{\widetilde{a}_{1}}>\right) \\
<\left(\underline{h_{1}}, h_{1}, \overline{h_{1}}\right), w_{\widetilde{b}_{1}}, u_{\widetilde{b}_{1}}>-\lambda_{b}\left(<\left(\underline{\left(k_{b}\right.}, k_{b}, \overline{k_{b}}\right), w_{b}, u_{k_{b}}>-<\left(\underline{h_{1}}, h_{1}, \overline{h_{1}}\right), w_{\widetilde{b}_{1}}, u_{\widetilde{b}_{1}}>\right)\end{array}$ \\
\hline Unfair Expropriation Price & $\begin{array}{c}<\left(\underline{s}_{2}, s_{2}, \overline{s_{2}}\right), w_{\widetilde{a}_{2}}, u_{\widetilde{a}_{2}}> \\
\left.<\underline{h_{2}}, h_{2}, \overline{h_{2}}\right), w_{\widetilde{b}_{2}}, u_{\widetilde{b}_{2}}>-\lambda_{b}\left(<\left(\underline{k_{b}}, k_{b}, \overline{k_{b}}\right), w_{k_{b}}, u_{k_{b}}>-<\left(\underline{h_{2}}, h_{2}, \overline{h_{2}}\right), w_{\widetilde{b}_{2}}, u_{\widetilde{b}_{2}}>\right)\end{array}$ \\
\hline The Expropriator A & Resistance of Expropriated Person B \\
\hline Fair Expropriation Price & $\begin{array}{l}<\left(\underline{s}_{3}, s_{3}, \overline{s_{3}}\right), w_{\widetilde{a}_{3}}, u_{\widetilde{a}_{3}}>-\lambda_{a}\left(<\left(\underline{k_{a}}, k_{a}, \overline{k_{a}}\right), w_{k_{a}}, u_{k_{a}}>-<\left(\underline{s}_{3}, s_{3}, \overline{s_{3}}\right), w_{\widetilde{a}_{3}}, u_{\widetilde{a}_{3}}>\right) \\
<\left(\underline{h_{3}}, h_{3}, \overline{h_{3}}\right), w_{\widetilde{b}_{3}}, u_{\widetilde{b}_{3}}>-\lambda_{b}\left(<\left(\underline{k_{b}}, k_{b}, \overline{k_{b}}\right), w_{k_{b}}, u_{k_{b}}>-<\left(\underline{h_{3}}, h_{3}, \overline{h_{3}}\right), w_{\widetilde{b}_{3}}, u_{\widetilde{b}_{3}}>\right)\end{array}$ \\
\hline Unfair Expropriation Price & $\begin{array}{c}<\left(\underline{s}_{4}, s_{4}, \overline{s_{4}}\right), w_{\widetilde{a}_{4}}, u_{\widetilde{a}_{4}}>-\lambda_{a}\left(<\left(\underline{k_{a}}, k_{a}, \overline{k_{a}}\right), w_{k_{a}}, u_{k_{a}}>-<\left(\underline{s}_{4}, s_{4}, \overline{s_{4}}\right), w_{\widetilde{a}_{4}}, u_{\widetilde{a}_{4}}>\right), \\
<\left(\underline{h_{4}}, h_{4}, \overline{h_{4}}\right), w_{\widetilde{b}_{4}}, u_{\widetilde{b}_{4}}>-\lambda_{b}\left(<\left(\underline{k_{b}}, k_{b}, \overline{k_{b}}\right), w_{k_{b}}, u_{k_{b}}>-<\left(\underline{h_{4}}, h_{4}, \overline{h_{4}}\right), w_{\widetilde{b}_{4}}, u_{\widetilde{b}_{4}}>\right)\end{array}$ \\
\hline
\end{tabular}

The loss aversion reference values of the expropriator and the expropriated person are $<\left(\underline{k_{a}}, k_{a}, \overline{k_{a}}\right), w_{k_{a}}, u_{k_{a}}>$ and $<\left(\underline{k_{b}}, k_{b}, \overline{k_{b}}\right), w_{k_{b}}, u_{k_{b}}>$. Given that $<\left(\underline{k_{a}}, k_{a}, \overline{k_{a}}\right), w_{k_{a}}, u_{k_{a}}>$ is larger than $<\left(\underline{s}_{1}, s_{1}, \overline{s_{1}}\right), w_{\widetilde{a}_{1}}, u_{\widetilde{a}_{1}}>,<\left(\underline{k_{b}}, k_{b}, \overline{k_{b}}\right), w_{k_{b}}, u_{k_{b}}>$ is greater than $<\left(\underline{h_{1}}, h_{1}, \overline{h_{1}}\right), w_{\widetilde{b}_{1}}, u_{\widetilde{b}_{1}}>$. Therefore, considering loss aversion fairness, the utility of both the expropriator and the expropriated person decreases under the fair expropriation price-acceptance scenario. Moreover, under the unfair expropriation price-acceptance scenario, the utility of the expropriator under loss aversion preference and that affected by the profit-seeking preference have not changed; however, the utility of the expropriated person decreases significantly. Under the fair expropriation price-resistance and unfair expropriation priceresistance scenarios, the utilities of both the expropriator and the expropriated person decrease. Table 2 shows that the fairness equilibrium result of the loss aversion is consistent with that of the profit-seeking equilibrium result. During the compensation process for housing expropriation, expropriator $\mathrm{A}$ has decision-making power and initiative power for expropriation, for which the optimal strategy is pursuing an unfair expropriation price. If $<\left(\underline{h_{2}}, h_{2}, \overline{h_{2}}\right), w_{\widetilde{b}_{2}}, u_{\widetilde{b}_{2}}>-\lambda_{b}\left(<\left(\underline{k_{b}}, k_{b}, \overline{k_{b}}\right), w_{k_{b}}, u_{k_{b}}>-<\left(\underline{h_{2}}, h_{2}, \overline{h_{2}}\right), w_{\widetilde{b}_{2}}, u_{\widetilde{b}_{2}}>\right)$ is larger than $<\left(\underline{h_{4}}, h_{4}, \overline{h_{4}}\right), w_{\widetilde{b}_{4}}, u_{\widetilde{b}_{4}}>-\lambda_{b}\left(<\left(\underline{k_{b}}, k_{b}, \overline{k_{b}}\right), w_{k_{b}}, u_{k_{b}}>-<\left(\underline{h_{4}}, h_{4}, \overline{h_{4}}\right), w_{\widetilde{b}_{4}}, u_{\widetilde{b}_{4}}>\right)$, then expropriated person B is forced to accept unfair compensation, and unfair expropriation priceacceptance becomes the equilibrium result. In contrast, if the expropriated person chooses the resistance strategy and unfair expropriation price-resistance is the equilibrium result, then the expropriated person often chooses to become a "nail household" (household that refuses to move from the expropriated land for some reason) to resist expropriation. Therefore, the equilibrium result is the same under the profit-seeking and loss aversion preference scenarios. The main reason is that the two preferences are based on the "pure profit" preferences of the subjects, while the "pure profit" pursuit without the social fairness preference is difficult when attempting to achieve the goal of harmonious expropriation. To improve the subject's utility under the loss aversion fairness preference, strengthening the expropriator's supervision and reducing the utility under unfair expropriation price are necessary steps. Next, the expropriated person's expectation of the expropriation compensation is reasonably reduced and the expropriation compensation is improved. Therefore, considering the fairness preference of loss aversion, the fair compensation price for housing expropriation should be based on the profit-seeking fairness preference compensation $C$ and the compensation for the loss value of the loss aversion fair utility of the 
expropriated person. The assumption made is that the compensation is a function of the utility loss of the loss aversion fairness preference; that is, the fair compensation price = $C+f\left\{\lambda_{b}\left(<\left(\underline{k_{b}}, k_{b}, \overline{k_{b}}\right), w_{k_{b}}, u_{k_{b}}>-<\left(\underline{h_{1}}, h_{1}, \overline{h_{1}}\right), w_{\widetilde{b}_{1}}, u_{\tilde{b}_{1}}>\right)\right\}$.

\subsubsection{Interactive Fair Fuzzy Equilibrium Evaluation Model}

Fehr and Schmidt gave a detailed description of the fairness preference of subjects, arguing that people often have the following behavioral motives in real society: people are willing to sacrifice their own interests to help those who are kind to them and they are willing to sacrifice their interests to punish those who are mean to them. When the cost of sacrifice is smaller, the incentive is greater. In other words, when the benefit of subject $A$ is less than that of subject $B, A$ will envy $B$; when the benefit of subject $A$ is greater than that of subject $B, A$ will sympathize with $B$; the smaller the cost of sacrifice, the greater the motivation of subjects $A$ and $B$. When the reference point changes, this will also lead to changes of the subjects' preferences, which will affect the subjects' cognition and judgment of fairness. Fehr and Schmidt compared the payoffs for participants in the game and constructed the fairness preference utility function using a mathematical model, which was a basic model used to quantify the change of utility caused by the fairness preference of participants. Regarding housing expropriation compensation, the expropriator and the expropriated person will weigh their own interests and the interests of the other subject to judge the fairness of the result. Therefore, Fehr and Schmidt's inequity aversion model is suitable for the study of this paper. By referring to Fehr and Schmidt's inequity aversion model, the fairness game investigation for housing expropriation compensation is carried out and the game matrix for housing expropriation compensation under fairness preference is established. An expected utility function containing the psychological utility value of the fairness preference is constructed. An equilibrium analysis is carried out to obtain the equilibrium solution of fairness game. Therefore, the game equilibrium for housing expropriation compensation under the interaction of strategies and beliefs based on profitseeking preference is obtained. The utility function established by Fehr and Schmidt [34] with the other player's payoff as the reference point is shown in Equation (2):

$$
U_{i}(x)=x_{i}-\frac{\alpha_{i}}{n-1} \sum_{j \neq i} \max \left(x_{j}-x_{i}, 0\right)-\frac{\beta_{i}}{n-1} \sum_{j \neq i} \max \left(x_{i}-x_{j}, 0\right)
$$

where $n$ represents the number of subjects, $U_{i}$ is the utility level of the player to the order of $i, x_{i}$ is the income of player $i, \alpha_{a}$ and $\beta_{a}$ represent the inequity aversion coefficients of expropriator $\mathrm{A}$, and $\alpha_{b}$ and $\beta_{b}$ represent the inequity aversion coefficients of expropriated person $B$. Table 3 provides the interactive fair fuzzy equilibrium evaluation matrix for the housing expropriation compensation.

Table 3 shows that in housing expropriation compensation disputes, the expropriated person's income is often lower than the expropriator. Therefore, the utility function of the expropriated person mainly includes the psychological function of jealousy, while the utility function of the expropriator mainly includes the psychological function of guilt. When the expropriator has strong guilt, $\beta_{a}$ is larger. In other words, the greater the utility difference between the expropriator and the expropriated person, the stronger the negative effect of the expropriator under the fairness preference. Therefore, reducing the utility difference between associated subjects is conducive to improving their utility. If the expropriator's feeling of guilt is stronger, the fair expropriation price strategy is more likely to become a dominant strategy. If the expropriated person's envy weakens, their acceptance strategy will be better than the resistance strategy under the expropriator's fair expropriation price strategy, and the fair expropriation price-acceptance scenario becomes the consensus equilibrium. Therefore, the fair compensation price is the compensation for the loss value of the expropriated person's interactive fair utility, which is based on the profit-seeking fairness preference compensation $\mathrm{C}$. The compensation is assumed to be a function of the loss value of the interactive fair utility, namely fair compensation price $=\mathrm{C}+$ 


$$
\begin{aligned}
& f\left\{<\left(h_{1}, h_{1}, \overline{h_{1}}\right), w_{\widetilde{b}_{1}}, u_{\widetilde{b}_{1}}>-\alpha_{b} \times \max \left(<\left(\underline{s}_{1}, s_{1}, \overline{s_{1}}\right), w_{\widetilde{a}_{1}}, u_{\widetilde{a}_{1}}>-<\left(h_{1}, h_{1}, \overline{h_{1}}\right), w_{\widetilde{b}_{1}},\right.\right. \\
& \left.\left.u_{\widetilde{b}_{1}}>, 0\right)-\beta_{b} \times \max \left(<\left(h_{1}, h_{1}, \overline{h_{1}}\right), w_{\widetilde{b}_{1}}, u_{\widetilde{b}_{1}}>-<\left(\underline{s}_{1}, s_{1}, \overline{s_{1}}\right), w_{\widetilde{a}_{1}}, u_{\widetilde{a}_{1}}>, 0\right)\right\}
\end{aligned}
$$

Table 3. Interactive fair fuzzy equilibrium evaluation matrix.

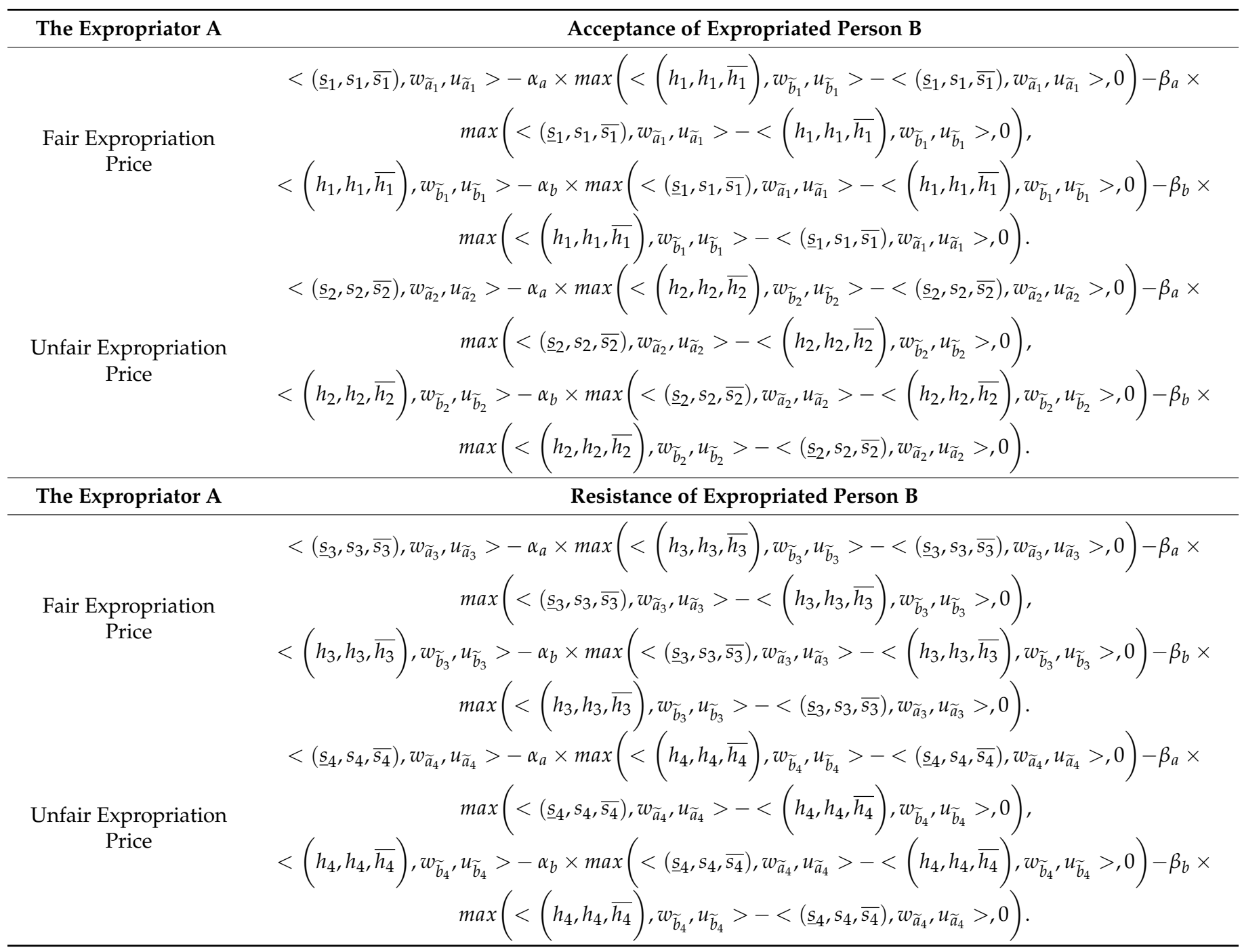

\subsection{Multidimensional Fair Fuzzy Equilibrium Evaluation Model}

Regarding the compensation for housing expropriation, meeting the multidimensional fairness preference demand of associated subjects is difficult if the compensation price is determined only by a single type of fairness. Therefore, this section puts three preferences into the same analytical framework to construct a multidimensional fairness equilibrium evaluation model. The associated subject's income is included in the same evaluation benchmark and the multidimensional fair equilibrium evaluation result is searched for. A multidimensional fuzzy equilibrium evaluation model is constructed as follows. The subjects' profit-seeking, loss aversion, and interactive fairness preferences are used as indicators of different project evaluation dimensions, and the strategies of the associated subjects are regarded as the project evaluation plans, namely plan 1 (fair expropriation price-acceptance), plan 2 (unfair expropriation price-acceptance), plan 3 (fair expropriation price-resistance), and plan 4 (unfair expropriation price-resistance). A decision evaluation method is introduced to transform the multidimensional fair fuzzy equilibrium evaluation problem of profit-seeking, loss aversion, and interactive fairness preferences into a 
priority selection problem for the multiattribute group decision. The optimal solution is the multidimensional fair fuzzy equilibrium evaluation.

\subsubsection{Multidimensional Fair Fuzzy Equilibrium Evaluation Matrix}

According to the aforementioned modeling ideas, the profit-seeking, loss aversion, and interactive fairness factors are put into the same analytical framework to construct a multidimensional fair fuzzy equilibrium evaluation matrix, as shown in Table 4.

Table 4. Multidimensional fair fuzzy equilibrium evaluation matrix.

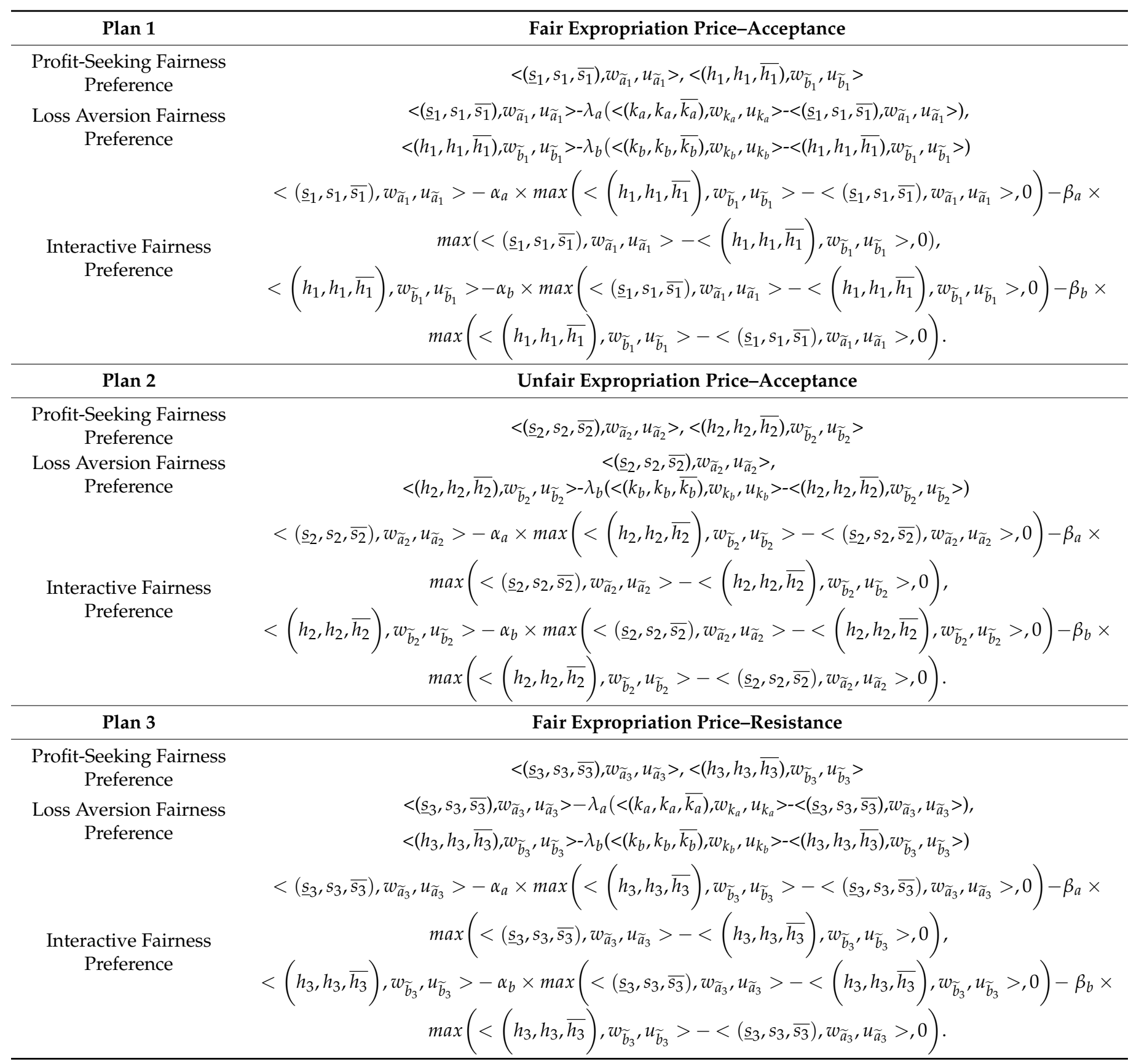


Table 4. Cont.

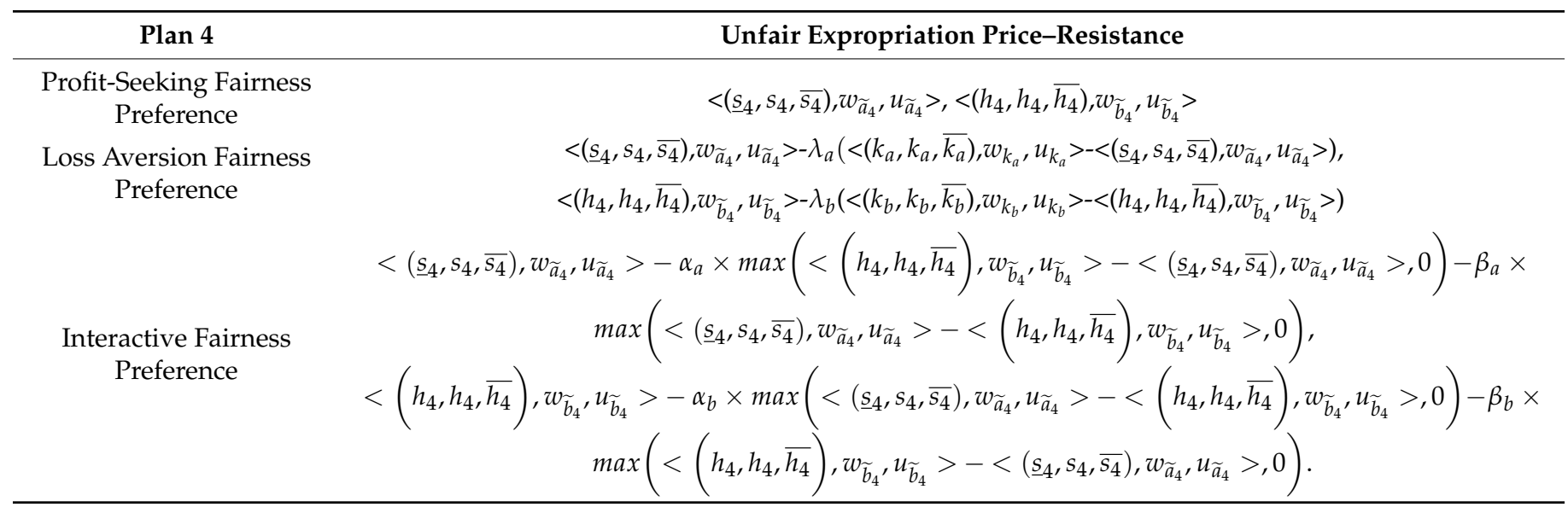

Using traditional equilibrium analysis methods to obtain the aforementioned multidimensional fair fuzzy equilibrium evaluation solution is difficult. This paper introduces the TOPSIS method to study the multidimensional fair fuzzy equilibrium evaluation problem.

3.3.2. Multidimensional Fair Fuzzy Equilibrium Evaluation Method Based on the TOPSIS Method

In the evaluation of the multidimensional fair fuzzy equilibrium, the TOPSIS method is introduced to solve the fuzzy equilibrium problem. The TOPSIS intuitionistic triangle method can be found in the literature [59]. The specific steps are as follows.

Step 1: Standardize the evaluation indicators to eliminate the influence of different physical dimensions on decision-making. Because the evaluation indicators in this article are all benefit-type evaluation indicators, Equation (3) is directly used.

$$
\widetilde{r}_{i j}=<\left(\frac{\underline{a}_{i j}}{\max \left\{\bar{a}_{i j}\right\}}, \frac{a_{i j}}{\max \left\{\bar{a}_{i j}\right\}}, \frac{\bar{a}_{i j}}{\max \left\{\bar{a}_{i j}\right\}}\right), w_{\widetilde{a}_{i j}}, u_{\widetilde{a}_{i j}}>
$$

Step 2: Calculate the weighted trigonometric intuitional fuzzy decision matrix $\widetilde{g}_{i j}=$ $W_{j} \times \widetilde{r}_{i j}=<\left(\underline{u}_{i j}, \mu_{i j}, \bar{\mu}_{i j}\right), w_{\widetilde{a}_{i j}}, u_{\widetilde{a}_{i j}}>$. The weight is calculated using subjective and objective weighting methods.

Step 3: Determine the positive ideal scheme $\left.\left(A^{+}=<\left(\underline{p}_{i j^{\prime}}, p_{i j}, \bar{p}_{i j}\right), w_{\widetilde{p}_{i j}}, u_{\widetilde{p}_{i j}}\right)>\right)$ and the negative ideal scheme $\left.\left(A^{-}=<\left(\underline{q}_{i j}, q_{i j}, \bar{q}_{i j}\right), w_{\widetilde{q}_{i j}}, u_{\widetilde{q}_{i j}}\right)>\right)$. Among these:

$$
\begin{aligned}
& A^{+}=<\left(\max \left\{\underline{\mu}_{i j}\right\}, \max \left\{\mu_{i j}\right\}, \max \left\{\bar{\mu}_{i j}\right\}\right), \max \left\{w_{\widetilde{a}_{i j}}\right\}, \min \left\{u_{\widetilde{a}_{i j}}\right\}> \\
& A^{-}=<\left(\min \left\{\underline{\mu}_{i j}\right\}, \min \left\{\mu_{i j}\right\}, \min \left\{\bar{\mu}_{i j}\right\}\right), \min \left\{w_{\widetilde{a}_{i j}}\right\}, \max \left\{u_{\widetilde{a}_{i j}}\right\}>
\end{aligned}
$$

Step 4: Calculate the distance from each scheme to the positive and negative ideal scheme points.

$$
\begin{aligned}
& d^{+}\left(\widetilde{a}_{i}, A^{+}\right)=\sum_{j=1}^{n}\left[\frac{\gamma}{4} \mid\left(\underline{\mu}_{i j}+2 \times \mu_{i j}+\bar{\mu}_{i j}\right) w_{\widetilde{a}_{i j}}-\left(\left(\underline{p}_{i j}+2 \times p_{i j}+\bar{p}_{i j}\right) w_{\widetilde{p}_{i j}}\left|+\frac{1-\gamma}{4}\right|\left(\underline{\mu}_{i j}+2 \times \mu_{i j}+\bar{\mu}_{i j}\right)\left(1-u_{\widetilde{a}_{i j}}\right)-\left(\left(\underline{p}_{i j}+2 \times p_{i j}+\bar{p}_{i j}\right)\left(1-u_{\tilde{p}_{i j}}\right) \mid\right]\right.\right. \\
& d^{-}\left(\widetilde{a}_{i}, A^{-}\right)=\sum_{j=1}^{n}\left[\frac{\gamma}{4} \mid\left(\underline{\mu}_{i j}+2 \times \mu_{i j}+\bar{\mu}_{i j}\right) w_{\widetilde{a}_{i j}}-\left(\left(\underline{q}_{i j}+2 \times q_{i j}+\bar{q}_{i j}\right) w_{\widetilde{q}_{i j}}\left|+\frac{1-\gamma}{4}\right|\left(\underline{\mu}_{i j}+2 \times \mu_{i j}+\bar{\mu}_{i j}\right)\left(1-u_{\widetilde{a}_{i j}}\right)-\left(\left(\underline{q}_{i j}+2 \times q_{i j}+\bar{q}_{i j}\right)\left(1-u_{\widetilde{q}_{i j}}\right) \mid\right]\right.\right.
\end{aligned}
$$

Step 5: Calculate the comprehensive evaluation index of each scheme.

$$
C_{i}=\frac{d_{i}^{+}}{d_{i}^{+}+d_{i}^{-}}
$$


Among the above factors, a smaller $C_{i}$ value indicates a better scheme. Because two subjects are involved in each scheme, when determining the optimal equilibrium evaluation plan, comprehensively considering the optimum reaction of the associated subjects is still necessary to obtain an equilibrium solution.

The fair compensation price based on the multidimensional fairness preference can be obtained in two ways. One way is to consider the loss value of the profit-seeking, loss aversion, and interactive fairness preferences in the same housing expropriation compensation project at the same time; that is, the fair housing expropriation compensation price $=C+$ $f\left\{\lambda_{b}\left(<\left(k_{b}, k_{b}, \overline{k_{b}}\right), w_{k_{b}}, u_{k_{b}}>-<\left(h_{1}, h_{1}, \overline{h_{1}}\right), w_{\widetilde{b}_{1}}, u_{\widetilde{b}_{1}}>\right)\right\}+f\left\{<\left(h_{1}, h_{1}, \overline{h_{1}}\right), w_{\widetilde{b}_{1}}\right.$, $u_{\widetilde{b}_{1}}>-\alpha_{b} \times \max \left(<\left(\underline{s}_{1}, s_{1}, \overline{s_{1}}\right), w_{\widetilde{a}_{1}}, u_{\widetilde{a}_{1}}>-<\left(h_{1}, h_{1}, \overline{h_{1}}\right), w_{\widetilde{b}_{1}}, u_{\widetilde{b}_{1}}>, 0\right)-\beta_{b} \times \max$ $\left.\left(<\left(h_{1}, h_{1}, \overline{h_{1}}\right), w_{\widetilde{b}_{1}}, u_{\widetilde{b}_{1}}>-<\left(\underline{s}_{1}, s_{1}, \overline{s_{1}}\right), w_{\widetilde{a}_{1}}, u_{\widetilde{a}_{1}}>, 0\right)\right\}$. Another approach is to adopt the subjective weighting method and then the multidimensional fairness compensation price $=w_{1} C+w_{2} \times\left(C+f\left\{\lambda_{b}\left(<\left(k_{b}, k_{b}, \overline{k_{b}}\right), w_{k_{b}}, u_{k_{b}}>-<\left(h_{1}, h_{1}, \overline{h_{1}}\right), w_{\widetilde{b}_{1}}, u_{\widetilde{b}_{1}}>\right)\right\}\right.$ $+w_{3} \times\left\{C+f\left\{<\left(h_{1}, h_{1}, \overline{h_{1}}\right), w_{\widetilde{b}_{1}}, u_{\widetilde{b}_{1}}>-\alpha_{b} \times \max \left(<\left(\underline{s}_{1}, s_{1}, \overline{s_{1}}\right), w_{\widetilde{a}_{1}}, u_{\widetilde{a}_{1}}>-<\left(h_{1}\right.\right.\right.\right.$, $\left.\left.h_{1}, \overline{h_{1}}\right), w_{\widetilde{b}_{1}}, u_{\widetilde{b}_{1}}>, 0\right)-\beta_{b} \times \max \left(<\left(h_{1}, h_{1}, \overline{h_{1}}\right), w_{\widetilde{b}_{1}}, u_{\widetilde{b}_{1}}>\right)-<\left(\underline{s}_{1}, s_{1}, \overline{s_{1}}\right), w_{\widetilde{a}_{1}}, u_{\widetilde{a}_{1}}>$, $0)\}\}$.

\section{Case Analysis}

The case data are from the "How Did I Become a Nail Household" report from the Law Today shown on CCTV on 19 April 2016, as well as from "The Nail Household Asked for 30 Million Yuan Relocation Compensation but the House is Demolished, and the Construction Period for Metro Line 6 in the City Has Been Delayed" report on 18 March 2016 by Changjiang Network news center [60].

\subsection{Case Overview}

In 2013, the district government issued a house expropriation decision, [2013] No. 5, "Announcement of Housing Expropriation Decision", and simultaneously announced the "Compensation Plan." The expropriated house was a one-story building in a village with an area of 287.51 square meters. The housing appraisal agency for the open selection process evaluated its value at 15.08 million yuan. The expropriated person was dissatisfied with the "House Expropriation Compensation Decision" made by the district government in 2015 and found another appraisal company to conduct a review of this expropriated house, which found that the evaluation result was approximately 26 million yuan. The expropriated person proposed 30 million yuan as compensation. However, the negotiations failed and the expropriated person applied to the municipal government for administrative reconsideration and cancellation of the "House Expropriation Compensation Decision." The district government applied to the Intermediate People's Court of the City to implement the "House Expropriation Compensation Decision", citing that the plaintiff's house was not demolished in time, which seriously affected the implementation of the Metro Line 6 project that was scheduled to be completed by the end of 2016. Moreover, the house had serious potential safety hazards that affected citizens' travel safety. At the same time, the district government also made a written commitment in accordance with the law and provided a special expropriation account number in a bank with a balance of 228 million yuan as a guarantee. On 17 March 2016, the house was demolished. 


\subsection{Multidimensional Fuzzy Equilibrium Evaluation of the Case}

Because the case did not involve the government's expropriation income, the expropriator and the expropriated person failed to reach an agreement regarding compensation. Thus, the revenues for both the expropriator and the expropriated person are uncertain. This paper uses the trigonometric intuitional fuzzy numbers to measure the utility of the associated subjects and assumes that the utility is a linear function of income and cost. Under the profit-seeking fairness preference, the fair price compensation for the project is 15.08 million yuan, as estimated by a housing appraisal agency for an open selection process. However, this value remains uncertain because the compensation has not yet been implemented. Therefore, the most likely value for the expropriated house is assumed to be 15.08 million yuan and the minimum compensation is 0.9 times 15.08 million yuan, or 13.572 million yuan. If the maximum compensation is 1.1 times 15.08 million yuan, or 16.588 million yuan, then the fuzzy compensation number for the fair price of the housing expropriation project is $\langle(1357.2,1508,1658.8), 0.7,0.2\rangle$. According to the sales prices of the commercial housing market in the region, the most likely income for the government for the expropriation is estimated at 44.66 million yuan. The minimum income is 40.194 million yuan and the maximum is 49.126 million yuan, which are 0.9 and 1.1 times the most likely income, respectively. Then, the fuzzy number for the income is $<(4019.4,4466,4912.6), 0.8,0.1>$. Under the influence of the profit-seeking fairness preference, the expropriator's utility is $\langle(2360.6,2958,3555.4), 0.7,0.2\rangle$, which is collected at a fair price and accepted by the expropriated person, and their utility is $<(1357.2,1508,1658.8), 0.7,0.2>$. Assuming that the government expropriates the house at an unfair price, the most likely value for the housing expropriation compensation is 0.8 times the fair price, or 12.064 million yuan. The minimum and maximum values are 0.9 and 1.1 times the most likely compensation, respectively, while the fuzzy number is $<(1085.76,1206.4,1327.04), 0.7,0.2>$. Under the influence of the profit-seeking fairness preference, the expropriator adopts the unfair expropriation price strategy. The utility that the expropriated person accepts is $<(2692.36,3259.6,3826.84), 0.7,0.2>$ and the utility loss is estimated to be $<(200,210,230), 0.7,0.2>$ for resistance. Under such circumstances, the utility loss of the expropriator against the resistance is $\langle(300,320,350), 0.8,0.1\rangle$. Considering that the expropriated person eventually obtains fair compensation for the resistance, when the expropriated person resists, the utility of the expropriator's fair and unfair prices is $\langle(2010.6,2638,3255.4), 0.7,0.2\rangle$, while the utility for the expropriated person is < $(1127.2,1298,1458.8), 0.7,0.2>$. In the fairness equilibrium evaluation of loss aversion, the reference dependency value of the expropriator is $\langle(2692.36,3259.6,3826.84), 0.7,0.2\rangle$, while the reference dependency values of the expropriated house are calculated using the evaluation result from the other appraisal company employed by the expropriated person and by the expected compensation of the expropriated person; that is, 26 million yuan and 30 million yuan, respectively. Then, the reference dependency value of the expropriated person is $\left\langle(2600,2860,3000), 0.7,0.2>\right.$. Set $\lambda_{a}=\lambda_{b}=1, \alpha_{a}=\alpha_{b}=1, \beta_{a}=\beta_{b}=0.5$. Substituting the above data into Equations (1) and (2), the utility results for the expropriator and the expropriated person under profit-seeking, loss aversion, and interactive fairness preferences are obtained and then substituted into Table 4. After adjustment, Table 5 is obtained.

We use the multiattribute group decision-making TOPSIS method introduced in Section 3.2.2 to process the data in Table 5, and finally according to the distance of each plan to the positive and negative ideal value and the comprehensive evaluation index, the optimal plan for the housing expropriation compensation is obtained. First of all, according to Equation (3), the basic data in Table 5 are standardized. Because some of the resultant values are negative, directly applying Equation (3) is unreasonable. Therefore, the data in this part are calculated in accordance with the equation $\dot{x}_{i j}=x_{i j}-\min _{i j}$, then Equation (3) is used to conduct the normalization processing for these data. The weight of each evaluation criterion is obtained through the expert consultation method, in which the weight of profit-seeking fairness is 0.4 , while the weights of the loss aversion and 
interactive fairness are 0.3. $w_{1}=0.4, w_{2}=w_{3}=0.3$, respectively. After the normalization weighted data processing, we use the equation $\widetilde{g}_{i j}=W_{j} \times \widetilde{r}_{i j}=<\left(\underline{\mu}_{i j}, \mu_{i j}, \bar{\mu}_{i j}\right), w_{\widetilde{a}_{i j}}, u_{\widetilde{a}_{i j}}>$ to calculate the weighted trigonometric intuitionistic fuzzy decision matrix. Substituting the calculation results into Equations (4) and (5), the following conclusions can be reached.

Table 5. Multidimensional fuzzy equilibrium evaluation matrix of the case.

\begin{tabular}{cc}
\hline Plan & Profit-Seeking Fairness \\
\hline Fair expropriation price-acceptance & $<(2360.6,2958,3555.4), 0.7,0.2>,<(1357.2,1508,1658.8), 0.7,0.2>$ \\
Unfair expropriation price-acceptance & $<(2692.36,3259.6,3826.84), 0.7,0.2>,<(1085.76,1206.4,1327.04), 0.7,0.2>$ \\
Fair Expropriation price-resistance & $<(2010.6,2638,3255.4), 0.7,0.2>,<(1127.2,1298,1458.8), 0.7,0.2>$ \\
Unfair Expropriation price-resistance & $<(2010.6,2638,3255.4), 0.7,0.2>,<(1127.2,1298,1458.8), 0.7,0.2>$ \\
\hline Plan & Loss Aversion Fairness \\
\hline Fair expropriation price-acceptance & $<(894.36,2656.4,4418.44), 0.7,0.2>,<(-285.6,156,717.6), 0.7,0.2>$ \\
Unfair expropriation price-acceptance & $<(1557.88,3259.6,4961.32), 0.7,0.2>,<(-828.48,-447.2,54.08), 0.7,0.2>$ \\
Fair Expropriation price-resistance & $<(194.36,2016.4,3818.44), 0.7,0.2>,<(-745.6,-264,317.6), 0.7,0.2>$ \\
Unfair Expropriation price-resistance & $<(194.36,2016.4,3818.44), 0.7,0.2>,<(-745.6,-264,317.6), 0.7,0.2>$ \\
\hline Plan & Interactive Fairness \\
\hline Fair expropriation price-acceptance & $<(-1457.66,1406.2,4330.06), 0.7,0.2>,<(-4989.64,-2344.4,540.84), 0.7,0.2>$ \\
Unfair expropriation price-acceptance & $<(-1337.02,1406.2,4209.42), 0.7,0.2>,<(-6618.28,-4154,-1449.72), 0.7,0.2>$ \\
Fair Expropriation price-resistance & $<(-2087.66,876.2,3880.06), 0.7,0.2>,<(-5309.64,-2544.4,440.84), 0.7,0.2>$ \\
Unfair Expropriation price-resistance & $<(-2087.66,876.2,3880.06), 0.7,0.2>,<(-5309.64,-2544.4,440.84), 0.7,0.2>$ \\
\hline
\end{tabular}

The positive ideal scheme for the expropriator's trigonometric intuitional fuzzy numbers is: $\quad A_{g}^{+}=(<(0.333,0.367,0.400), 0.7,0.2>,<(0.094,0.197,0.300), 0.7,0.2>$, $<(0.052,0.097,0.292), 0.7,0.2>)$;

The positive ideal scheme for the expropriated person's trigonometric intuitional fuzzy numbers is: $\left.A_{r}^{+}=(<(0.327,0.364,0.400), 0.7,0.2\rangle,<(0.227,0.252,0.300), 0.7,0.2\right\rangle$, $<(0.245,0.273,0.300), 0.7,0.2>)$;

The negative ideal scheme for the expropriator's trigonometric intuitional fuzzy numbers is: $\left.\quad A_{g}^{-}=(<(0.210,0.276,0.340), 0.7,0.2\rangle,<(0.012,0.122,0.231), 0.7,0.2\right\rangle$, $<(0.000,0.061,0.269), 0.7,0.2>)$;

The negative ideal scheme for the expropriated person's trigonometric intuitional fuzzy numbers is: $A_{r}^{-}=(<(0.262,0.291,0.320), 0.7,0.2>,<(0.000,0.000,0.023), 0.7,0.2>$, $<(0.000,0.000,0.000), 0.7,0.2>)$.

In this case, considering that the subjects of the expropriation are risk-neutral, $\gamma=0.5$ is set. Substituting the above results into Equations (6)-(8), the distances from each scheme to its positive and negative ideal scheme points and the comprehensive evaluation index value of each scheme are calculated. The specific data are shown in Table 6.

Table 6. Distance from each scheme to positive and negative ideal scheme points and the comprehensive evaluation index values.

\begin{tabular}{cccc}
\hline Plan & $\begin{array}{c}\text { The Distance to the } \\
\text { Positive Ideal } \\
\text { Scheme Points }\end{array}$ & $\begin{array}{c}\text { The Distance to the } \\
\text { Negative Ideal } \\
\text { Scheme Points }\end{array}$ & $\begin{array}{c}\text { Comprehensive } \\
\text { Evaluation Index } \\
\text { Value }\end{array}$ \\
\hline $\begin{array}{c}\text { Fair expropriation } \\
\text { price-acceptance }\end{array}$ & $(0.051,0)$ & $(0.082,0.448)$ & $(0.382,0)$ \\
$\begin{array}{c}\text { Unfair expropriation } \\
\text { price-acceptance }\end{array}$ & $(0,0.03)$ & $(0.133,0)$ & $(0,1)$ \\
$\begin{array}{c}\text { Fair expropriation } \\
\text { price-resistance } \\
\begin{array}{c}\text { Unfair expropriation } \\
\text { price-resistance }\end{array}\end{array}$ & $(0.133,0.195)$ & $(0,0.253)$ & $(1,0.435)$ \\
\hline
\end{tabular}


Each housing expropriation compensation scheme includes two associated subjects. Therefore, when determining the multidimensional fair fuzzy equilibrium evaluation, the optimum reaction of the associated subjects must be considered to achieve a consistent equilibrium solution. The data in Table 6 show that it is difficult for the associated subjects to reach agreement on the minimum value of the comprehensive evaluation index. The agreement is one-sided if only a single behavioral preference for the profit-seeking, loss aversion, or interactive fairness preferences is considered, and judging the influence of the subjects' behavioral preference against the result of the game will be difficult. Therefore, under the effect of multidimensional fairness, the dominant expropriator can adjust the strategy appropriately and choose the fair expropriation strategy with the second-lowest comprehensive evaluation index. In this way, the best strategy for the expropriated person is acceptance, then the fair expropriation price-acceptance strategy is presented as the consensus balance-a harmonious housing expropriation result is achieved and the expropriation compensation dispute is resolved.

Therefore, the expropriator compensates for the housing expropriation project based on the valuation of 15.08 million yuan, as determined by the publicly selected housing appraisal agency. This compensation price neglects the loss aversion and interactive fairness preferences of the expropriated person. Moreover, the 15.08 million yuan can be moderately corrected upward by the loss aversion and interactive fairness preferences. In this way, the harmonious expropriation situation (fair expropriation price-acceptance) will appear, and the housing expropriation process can be implemented.

\section{Conclusions and Policy Implications}

\subsection{Conclusions}

This paper uses the game equilibrium logic for the interaction of strategy and beliefs to study the multidimensional fair fuzzy equilibrium problem of compensation for housing expropriation using two subjects-multiple preferences and multistrategies. This paper also uses the TOPSIS method to transform the multidimensional fair fuzzy equilibrium problem of housing expropriation compensation into a multiattribute group decisionmaking sorting problem. Then, the optimal combination plan-the multidimensional fair fuzzy equilibrium evaluation solution-is obtained. This method can effectively reduce the difficulty of solving the game equilibrium scenario and can be used for practical problems, such as investment decision-making and benefit distribution, under the influence of multiple behavior preferences. The conclusions of this paper are as follows.

First, incorporating the effects of the subjects' profit-seeking, loss aversion, and interactive fairness preferences into the consideration of housing expropriation compensation will bring about different expropriation compensation results. When a subject is affected by multiple behavioral preferences, their behavioral strategy choices will change. Under the interactions of belief strategies, the behavioral selection strategies of other subjects will be influenced and the expropriation compensation result will change. When fairness preference corrections are made to the expropriation compensation market value, the obtained fair compensation price under the multidimensional fairness preference scenario is conducive to achieving the desirable housing expropriation equilibrium (fair price collection-acceptance) and improves the expropriated person's acceptance probability. The implementation of the expropriation process allows social welfare to be maximized and housing expropriation compensation disputes to be resolved.

Second, by innovatively introducing decision-making theory methods, the strategies of the expropriator and expropriated person are adopted as the decision-making plan, the decision theory methods are introduced, and the multidimensional fair fuzzy equilibrium problem is transformed into an equilibrium evaluation problem, effectively reducing the difficulty of solving this complicated game problem.

Third, as the leading party to the housing expropriation compensation, the expropriator should actively promote fair expropriation price, reverse the expropriated person's 
preference under the influence of the profit-seeking and loss aversion preferences, stimulate their interactive fairness preference, and achieve a harmonious expropriation result.

Fourth, to resolve the disputes over compensation for housing expropriation and to improve the expropriated person's sense of gain, the influence of the associated subjects multidimensional fairness preferences on the expropriated person's utility should be considered. To achieve fair compensation for housing expropriation, the multidimensional fairness preference for the expropriation compensation market price should be revised.

In addition, this research field can also be studied from other directions; due to the large areas of agricultural land in China, the situation for the farmland expropriation is more intense than that of housing expropriation. The research background can be replaced with farmland expropriation to allow a multidimensional equilibrium evaluation of three subjects (in China, land expropriation involves three subjects: local government, village collective organization, and farmers), multiple preferences, and multiple strategies. In real housing expropriation compensation scenarios, the exchange is not simply a one-off transaction between the expropriator and the expropriated person, but rather a multistage, dynamic exchange is more in line with the actual housing expropriation scenarios. Therefore, the dynamic structure of the "game" can also be addressed to analyze changes in the preference structure of the associated subjects in the conflict game and the influence on the equilibrium results of the game, so as develop it into a multiagent and multistage dynamic game [61] and expand the general multidimensional equilibrium evaluation model based on multiple attribute group decision-making theory. Regarding the multidimensional fair fuzzy equilibrium evaluation model and method constructed in this paper, the scope of the research object can be expanded and the scope of the validation process can be developed from individual objects to universal objects, for example by applying the model and evaluation method to pooled data of housing expropriation. The conclusions are summarized and comparatively analyzed to verify the scientificity and universality of the multidimensional fair fuzzy equilibrium evaluation model and method constructed in this paper.

\subsection{Policy Implications}

Based on the above conclusions, in order to make the governance measures for housing expropriation compensation more targeted and forward-looking, the following policy recommendations are made.

The first is to establish an expropriation supervision mechanism to reduce the occurrence of mass conflicts and ensure the stable development of society. Third-party supervisory agencies can be introduced to regulate the government's expropriation activities, strengthen the supervision and prevention of extreme behaviors by expropriated individuals, establish emotional counseling agencies, and avoid the negative impacts of expropriation compensation conflicts on economic and social development. The interactions of the belief strategies of the expropriator and the expropriated will enter a virtuous circle and the probability of harmonious expropriation will be improved.

The second is to establish and improve the government's information liaison and feedback institutions, and to attach importance to responding to the doubts raised by the expropriated individuals. The right of the expropriated individuals to know pertaining to the information expropriation process should be protected and expropriation compensation disputes caused by information mismatch should be reduced. An active feedback should be formed for the doubts raised by the expropriated individuals to improve their disadvantaged position in the expropriation compensation process, and an equal dialogue should be established between the expropriator and the expropriated. A set of continuous response mechanism should be established, the entire process should be proceduralized and standardized, and problem-handling should be turned from a supervisor-oriented to objective-oriented process. The perceive fairness of the expropriation process should be assessed through feedback, which should enhance confidence in the government and avoid expropriation compensation conflicts caused by poor communication. 
China's housing expropriation and compensation system needs to be further improved to promote the sustainable development of urbanization. The advancement of urbanization requires the transformation of old urban areas, and housing expropriation has become one of the most important tasks in this process. The dissatisfaction of the expropriated reflects the defects of the housing expropriation system, which is also the root of the expropriation compensation disputes. Differing from peer research, our study found that only by simultaneously satisfying the fairness preferences of the expropriator and the expropriated under the influence of multiple behavioral preferences can both parties move from conflict to cooperation. Balancing and satisfying the needs of both parties and the common interests between the two have always been important issues for academic research.

Author Contributions: Conceptualization, Z.C., X.Z., Y.Z. (Yucheng Zou), K.H., and Y.Z. (Yanwei Zhang); methodology, Z.C. and X.Z.; validation, Z.C., X.Z., and Y.Z. (Yucheng Zou); formal analysis, X.Z.; data curation, Z.C. and X.Z.; writing—original draft preparation, Z.C. and X.Z.; writing—review and editing, Y.Z. (Yucheng Zou) and Y.Z. (Yanwei Zhang); project administration, Z.C.; funding acquisition, K.H. All authors have read and agreed to the published version of the manuscript.

Funding: This research was funded by the National Natural Science Foundation of China (No. 71671187).

Institutional Review Board Statement: Not applicable.

Informed Consent Statement: Not applicable.

Data Availability Statement: Not applicable.

Acknowledgments: The authors wish to thank the anonymous reviewers, whose insightful comments and helpful suggestions significantly contributed to improving this paper.

Conflicts of Interest: The authors declare no conflict of interest.

\section{References}

1. Lin, Q.W.; Tan, S.K.; Zhang, L.; Wang, S.L.; Wei, C.; Li, Y.N. Conflicts of land expropriation in China during 2006-2016: An overview and its spatio-temporal characteristics. Land Use Policy 2018, 76, 246-251. [CrossRef]

2. Hui, E.C.M.; Bao, H.J.; Zhang, X.L. The policy and praxis of compensation for land expropriations in China: An appraisal from the perspective of social exclusion. Land Use Policy 2013, 32, 309-316. [CrossRef]

3. Cheng, J.; Masser, I. Urban growth pattern modeling: A case study of Wuhan city, PR China. Landsc. Urban Plan. 2003, 62, 199-217. [CrossRef]

4. Report on the Work of the Chinese Government in 2019. Available online: http://www.gov.cn/zhuanti/2019qglh/2019lhzfgzbg/ (accessed on 5 March 2019). (In Chinese)

5. Chinese Family Panel Studies. Available online: http:/ / opendata.pku.edu.cn/dataverse/CFPS (accessed on 15 December 2017). (In Chinese)

6. Shan, L.P.; Yu, A.T.W.; Wu, Y.Z. Strategies for risk management in urban-rural conflict: Two case studies of land acquisition in urbanising China. Habitat Int. 2017, 59, 90-100. [CrossRef] [PubMed]

7. Han, H.Y.; Shu, X.F.; Ye, X.Y. Conflicts and regional culture: The general features and cultural background of illegitimate housing demolition in China. Habitat Int. 2018, 75, 67-77. [CrossRef]

8. $\mathrm{Wu}, \mathrm{Z} . \mathrm{Z}$. The interest appeal and expression mechanism of the vulnerable groups in urban renewal. Truth Seek. 2013, 5, 63-67. (In Chinese)

9. Zhang, W.Y. Game Theory and Information Economics; Shanghai People's Publishing House: Shanghai, China, 2004. (In Chinese)

10. Chen, Z.L.; Wang, W.J. Evolutionary Game Analysis of Governments and Polluting Firms Considering Environmental Tax Regulation. Manag. Rev. 2017, 29, 226-236. (In Chinese)

11. Wu, Z.F. The Game Analysis on the Stake-holders in the Reform of Real Estate Tax. J. Cent. Univ. Financ. Econ. 2011, 5, 1-5. (In Chinese)

12. Jiang, T. Preference structure, Belief Characteristics and Individual Decision Model-A review of research based on behavioral Economics paradigm. J. Zhongnan Univ. Econ. Law 2013, 2, 11-18. (In Chinese)

13. Guo, L.; Wang, L.H. The Pricing Dilemma and Conflicts in House Expropriation. Chin. Public Adm. 2015, 1, 21-26. (In Chinese)

14. Huang, Y.M.; Zhang, W.J.; Zhao, J.X. Actual gain, fairness cognition and residents' sense of gain. Mod. Econ. Res. 2017, 11, 1-10. (In Chinese)

15. Liu, R. Grey governance and land expropriation conflict. Academics 2018, 5, 43-56. (In Chinese)

16. Cao, Z.Y.; Zou, Y.C.; Zhao, X.; Hong, K.R.; Duan, K.F. Multidimensional fairness equilibrium evaluation of urban housing expropriation compensation based on VIKOR. Mathematics 2021, 9, 430. [CrossRef] 
17. Hong, K.R.; Zou, Y.C.; Zhang, Y.W.; Duan, K.F. The Weapon of the Weak: An Analysis of RDEU Game in the Conflict of Farmland Expropriation under the Influence of Emotion. Sustainability 2020, 12, 3367. [CrossRef]

18. Hui, E.C.M.; Bao, H.J. The logic behind conflicts in land acquisitions in contemporary China: A framework based upon game theory. Land Use Policy 2013, 30, 373-380. [CrossRef]

19. Liu, D.H.; Han, C.J.; Yin, L.J. Multi-scenario Evolutionary Game Analysis of Evolutionary Mechanism in Urban Demolition Mass Incident. Oper. Res. Manag. Sci. 2016, 1, 76-84. (In Chinese)

20. Li, Q.X.; Bao, H.J.; Peng, Y.; Wang, H.W.; Zhang, X.L. The Collective Strategies of Major Stakeholders in Land Expropriation: A Tripartite Game Analysis of Central Government, Local Governments, and Land-Lost Farmers. Sustainability 2017, 9, 648. [CrossRef]

21. Bao, H.J.; Wu, X.H.; Wang, H.W.; Li, Q.X.; Peng, Y.; Lu, S.B. Conflicts Induced by Different Responses to Land Expropriation Among the Farmers Involved During Urbanization in China. J. Artif. Soc. Soc. Simul. 2019, 22, 7. [CrossRef]

22. Hong, K.R.; Zou, Y.C.; Zhu, M.Y.; Zhang, Y.W. A Game Analysis of Farmland Expropriation Conflict in China under MultiDimensional Preference: Cooperation or Resistance? Land 2021, 10, 124. [CrossRef]

23. Zhang, Y.; Xie, H. Welfare Effect Evaluation of Land-Lost Farmers' Households under Different Livelihood Asset Allocation. Land 2019, 8, 176. [CrossRef]

24. Xie, S.Y. Evolutionary game theory under bounded rationality. J. Shanghai Univ. Financ. Econ. 2001, 5, 3-9. (In Chinese)

25. Williamson, E. The economics of organization: The transaction cost approach. Am. J. Sociol. 1981, 87, 548-577. [CrossRef]

26. Camerer, C.F. Progress in behavioral game theory. J. Econ. Perspect. 1997, 11, 167-188. [CrossRef]

27. Dong, Z.Q.; Hong, X.X. Behavioral Labor Economics: Behavioral Economics' Contributions to Labor Economics. Econ. Rev. 2010, 5, 132-138. (In Chinese)

28. Bolton, G.E.; Zwick, R. Anonymity versus punishment in ultimatum bargaining. Games Econ. Behav. 1995, 1, 95-121. [CrossRef]

29. Sanfey, A.G.; Rilling, J.K. the neural basis of economic decision-making in the ultimatum game. Science 2003, 5626, 1755-1758. [CrossRef]

30. Dirk, E.; Martin, S. Inequality aversion, efficiency, and maximin preferences in simple distribution experiments. Am. Econ. Rev. 2004, 4, 857-869.

31. Catherine, E.; Herbert, G. Blaming the messenger Notes on the current state. J. Behav. Organ. 2010, 73, 109-119.

32. Hong, K.R.; Liao, Y.L. The research on real estate acquisition compensation in urbanization-Instance of Changsha. Econ. Geogr. 2014, 7, 150-156. (In Chinese)

33. Rabin, M. Incorporating Fairness into Game Theory and Economics. Am. Econ. Rev. 1993, 83, 1281-1302.

34. Fehr, E.; Schmidt, K.M. A Theory of Fairness, Competition and Cooperation. Q. J. Econ. 1999, 114, 817-868. [CrossRef]

35. Bolton, G.E.; Ockenfels, A. ERC: A Theory of Equity, Reciprocity, and Competition. Am. Econ. Rev. 2000, 90, 166-193. [CrossRef]

36. Dufwenberg, M.; Kirchsteiger, G. A Theory of Sequential Reciprocity. Games Econ. Behav. 2004, 47, 268-298. [CrossRef]

37. Falk, A.; Fischbacher, U. A Theory of Reciprocity. Games Econ. Behav. 2006, 54, 293-315. [CrossRef]

38. Zhong, M.R.; Huang, J.B. The Analysis of development and explanatory of fairness preference models. Theory Pract. Financ. Econ. 2009, 6, 2-6.

39. Kohler, S. Altruism and fairness in experimental decisions. J. Econ. Behav. Organ. 2011, 1, 101-109. [CrossRef]

40. Raúl, L.P. The power of words: A model of honesty and fairness. J. Econ. Psychol. 2012, 33, 642-658.

41. Wang, Y.; Lu, X.H. The impact of housing expropriated person's fairness perception on compensation willingness of expropriation on state-owned land. China Land Sci. 2013, 9, 11-18.

42. Zhang, Y.F.; Zhang, Y. Construction of game model of land resource development and utilization based on fair preference. Stat. Decis. 2014, 24, 48-51.

43. Baldassarri, D. Cooperative Networks: Altruism, Group Solidarity, Reciprocity, and Sanctioning in Ugandan Producer Organizations. Am. J. Sociol. 2015, 121, 355-395. [CrossRef] [PubMed]

44. Liu, H.; Hong, K.R. Equilibrium evaluation of real estate expropriation compensation contract based on interactive fairness. Shandong Soc. Sci. 2016, 4, 138-142.

45. Wang, J.L.; Tong, B. Research on Income Inequality, Fairness Preference and Redistribution. J. Manag. World 2017, 6, 63-81. (In Chinese)

46. Wang, J.P.; Wang, Y. Decision model of supply chain considering fairness preference and sale efforts. J. Syst. Manag. 2018, 2, 374-383.

47. Zhang, C.; Zhang, J.; Han, G.H. Optimal ordering period and delayed payment decision in different fairness preference. J. Syst. Manag. 2020, 1, 129-139.

48. Kahneman, D.; Tversky, A. Prospect Theory: An Analysis of Decision Under Risk. Econometrica 1979, 47, 263-292. [CrossRef]

49. Thaler, R. Toward A Positive Theory of Consumer Choice. J. Econ. Behav. Organ. 1980, 1, 39-60. [CrossRef]

50. Tversky, A.; Kahneman, D. Advances in Prospect Theory Cumulative Representation of Uncertainty Econometrica. J. Risk Uncertain. 1992, 5, 297-323. [CrossRef]

51. Shalev, J. Loss Aversion in a Multi-period model. Math. Soc. Sci. 1997, 3, 203-226. [CrossRef]

52. Shalev, J. Loss Aversion Equilibrium. Int. J. Game Theory 2000, 29, 269-287. [CrossRef]

53. Gimpel, H. Loss Aversion and Reference-Dependent Preferences in Multi-Attribute Negotiations. Group Decis. Negot. 2007, 16, 303-319. [CrossRef] 
54. Driesen, B.; Perea, A.; Peters, H. Alternating offers bargaining with loss aversion. Math. Soc. Sci. 2012, 64, 103-118. [CrossRef]

55. Ahrens, S.; Pirschel, I.; Snower, D.J. A theory of Price Adjustment Under Loss Aversion. J. Econ. Behav. Organ. 2017, 134, 78-95. [CrossRef]

56. Enrico, G.; De, G. Loss Aversion with A State-dependent Reference Point. Manag. Sci. 2011, 57, 1094-1110.

57. Xu, F.M.; Shi, Y.W.; Li, O.; Zhang, H.; Li, Y. Mechanisms and Measures of the Public' Sense of Income Unfairness: Dual Viewpoint of Reference Dependence and Loss Aversion. Adv. Psychol. Sci. 2016, 5, 665-675. (In Chinese) [CrossRef]

58. Shi, J.; Zhu, J. Behavior choice of people whose house will be dismantled from the point of view of game theory. Urban Probl. 2013, 4, 72-77.

59. Zhang, M.J.; Nan, J.X.; Li, D.F.; Li, Y.X. TOPSIS for MADM with Trigonometric intuitional fuzzy numbers. Oper. Res. Manag. Sci. 2012, 21, 96-101. (In Chinese)

60. The Nail Household Asked the 30 Million Yuan Relocation Compensation but the House is Demolished, and the Construction Period of Metro Line 6 in a City Has Been Delayed. Available online: http:/ / news.cjn.cn/sywh/201603/t2797907.htm (accessed on 18 March 2016). (In Chinese).

61. Xie, X.Y.; Wang, Y.H.; Li, X.Z. The usage analysis and policy choice of CNG taxis based on a multi-stage dynamic game model. Comput. Econ. 2019, 4, 1379-1390. [CrossRef] 